\title{
Nutritional composition of horsemeat compared to white meat (chicken and duck)
}

\author{
Do-Hee Kim ${ }^{1}$, Kyung-Won Kim ${ }^{1}$, Young-Hoon $\mathrm{Kim}^{1}$, Joo-Ah Kim , Jun Kim , \\ Kwang-Deog Moon ${ }^{2,3 *}$ \\ ${ }^{1}$ Jeju Livestock Development Institute, Jeju 63078, Korea \\ ${ }^{2}$ School of Food Science and Biotechnology, Kyungpook National University, Daegu 41566, Korea \\ ${ }^{3}$ Food and Bio-Industry Research Institute, Kyungpook National University, Daegu 41566, Korea
}

\section{백색육(오리고기, 닭고기)과 말고기의 식품학적 성분 비교}

\author{
김도희 ${ }^{1} \cdot$ 김경원 $^{1} \cdot$ 김영훈 $^{1} \cdot$ 김주아 $^{1} \cdot$ 김준 $^{1} \cdot$ 문광덕 $^{2,3 *}$ \\ ${ }^{1}$ 제주특별자치도 축산진흥원, ${ }^{2}$ 경북대학교 식품공학부, ${ }^{3}$ 경북대학교 식품생물산업연구소
}

\begin{abstract}
To enhance the consumption of horse meat, its nutritional composition was analyzed and compared to that of white meat (i.e., chicken and duck), which consumers consider healthy. Horse meat samples used in the experiment were classified by breed and grade as follows: Jeju horse (grade $1^{+}$and 1), Jeju crossbred horse (grade 1 and 2), Thoroughbred (no grade), and cuts (loin, chuck roll, and arm picnic). In an analysis of general components and cholesterol, the horse meat was confirmed as a low-fat, high-protein, and low-cholesterol food material. In an amino acid analysis, horse meat contained a higher proportion of essential amino acids than white meat. The fatty acid compositions were also analyzed. The content of linolenic acid, an essential fatty acid, was significantly higher in all horse meat groups than in Ross chicken and Pekin duck meat. The content of palmitoleic acid showed similar results. In a mineral analysis, the levels of $\mathrm{Fe}$ and $\mathrm{Zn}$ in horse meat were higher than those of white meat. The mineral content was as follows except for the leg of shite meat: $\mathrm{K}>\mathrm{P}>\mathrm{Na}>\mathrm{Mg}>\mathrm{Ca}>\mathrm{Zn}>\mathrm{Fe}$.
\end{abstract}

Key words : horse meat, chicken meat, duck meat, nutritional composition, fatty acids

\section{서 론}

현대인들의 건강에 대한 관심이 고조됨에 따라 육류 시 장에도 웰빙 바람이 불면서 백색육 선호 추세가 여전히 이어지고 있다. 그 중심에는 닭고기, 오리고기가 있으며, 말고기 또한 웰빙 식육 자원으로 손색이 없으나, 이들에 비해 비선호되는 경향이 있다. 이는 말고기처럼 알려지지 않은 식품에 대해 부정적 태도를 가지고 있기 때문인 것으

*Corresponding author. E-mail : kdmoon@knu.ac.kr Phone : 82-53-950-5771, Fax : 82-53-950-6772

Received 28 May 2015; Revised 21 August 2015; Accepted 7 September 2015.

Copyright (c) The Korean Society of Food Preservation. All rights reserved.
로 나타났으며, 말고기에 대한 소비자 태도를 조사한 결과, 말고기에 대한 정보는 소비자 태도에 유의한 정(+)의 영향 을 미치는 것으로 나타났다. 음식 선택 동기의 43개 항목 중 “건강”이 가격, 감각적 매력, 기분, 편리성 다음 순인 5 위를 차지하였으며, 국내 소비자들의 호의적 태도 형성을 위해서는 말고기의 장점을 알릴 필요가 있다고 보고된 바 있어 말고기의 식품학적 특성을 부각시켜 홍보할 필요성이 대두되고 있다 $(1,2)$.

농림축산식품부에서 매년 발간하는 농림축산식품 주요 통계(2013)의 국민 1인당 연간 소비량은 2012년 기준 쇠고 기 $9.7 \mathrm{~kg}$, 돼지고기 $19.2 \mathrm{~kg}$, 닭고기 $11.6 \mathrm{~kg}$ 이며, 말고기와 유사한 사례로 볼 수 있는 오리고기는 풍부한 불포화지방산 등 식품학적 성분을 부각시켜 지속적으로 홍보한 결과, 국 민 1 인당 연간 소비량이 $0.45 \mathrm{~kg}(1998)$ 에서 $3.4 \mathrm{~kg}(2012)$ 으 
로 증가한 바 있다. 말고기는 국제연합식량농업기구(FAO) 에서 공식적인 통계로 관리되고 있을 정도로 많은 국가에서 식품으로 취급되고 소비되며, 이탈리아, 프랑스, 벨기에, 네덜란드 등 유럽의 몇몇 국가들에서 중요한 식육자원으로 이용되고 있다(3). 축산물품질평가원 제주지원에 따르면 2011년 777두, 2012년 779두, 2013년 805두가 제주지역에 서 말고기 생산을 위해 도축되었다.

국내에서는 말고기를 이용한 가공식품 개발, 말고기에 대한 소비자 태도와 구매의도 등 말고기 활용 제고방안에 관한 연구가 주를 이루고 있으며 $(1,4,5)$, 국외에서는 우리나 라에 비해 말고기의 대중화가 이루어져 있기 때문에 마육의 저장 안정성(품질 변화 모니터링) 및 안전성(미생물 오염 도)에 대한 연구가 진행되었다(6,7). 말고기를 비롯하여 닭 고기, 오리고기 각각에 대한 영양성분 관련 연구는 있으나, 이들을 동시에 분석한 연구는 전무한 실정이다. 이에 본 연구에서는 건강에 좋은 육류로 알려져 있는 닭고기, 오리 고기와 말고기의 식품학적 특성을 비교하여 이에 따른 기초 자료를 얻고자 하였다.

\section{재료 및 방법}

\section{재 료}

재료는 닭고기 6점, 오리고기 6점, 말고기 45점으로 닭고 기는 우리나라 닭 사육의 대표적인 품종인 로스(Ross) 품종 으로 32 일령이었으며, 중량은 $1,490.52 \pm 24.79 \mathrm{~g}$ 이었다. 오 리고기는 페킨(Pekin) 품종으로 41일령이었으며, 중량은 $2354.93 \pm 90.76 \mathrm{~g}$ 이었다. 이 때 시료는 동일 품종, 동일 사료 급여 개체로 선별하여 도축 즉시 진공포장하였으며, 부위 별(가슴살, 다리살)로 이용하였다. 말고기는 제주마 $\left(1^{+}, 1\right.$ 등 급), 제주산마(1, 2등급), 더러브렛(등외)으로 품종별, 등급 별 부분육(등심, 목심 및 앞다리)으로 구입하였으며, 도축 후 등급판정이 완료되는 대로 부위별로 진공포장하여 실험 에 이용하였다.

\section{일반성분}

일반성분은 $\mathrm{AOAC}$ 방법에 준하여 분석하였다(8). 수분 및 조지방 함량은 CEM 자동추출장치(Labwave 9000/FAS 9001, CEM Corp., Matthews, NC, USA)를 이용하여 측정하 였다. 조단백질은 Kjeltec system(Kjeltec Auto 2400/2460, Foss Tecator AB, Hoganas, Sweden)을 이용하여 분석하였으 며, 조회분은 회분분석기(MAS 7000, CEM Corp., Matthews, NC, USA)를 이용하여 측정하였다.

\section{콜레스테롤}

콜레스테롤 함량은 시료 $5 \mathrm{~g}$ 에 $60 \% \mathrm{KOH}$ (d.w.) $8 \mathrm{~mL}$ 와 $40 \mathrm{~mL}$ 의 반응용 알콜(EtOH : MeoH : isoproylacohol $=90$
$: 5: 5)$ 을 넣고 water bath $\left(100^{\circ} \mathrm{C}\right)$ 에서 60 분 동안 검화시키고 $50^{\circ} \mathrm{C}$ 로 냉각시킨 후 반응용 알콜 $60 \mathrm{~mL}$ 를 냉각관을 통해 주입시켰다. 분액여두를 이용하여 benzene, $1 \mathrm{~N} \mathrm{KOH}, 0.5$ $\mathrm{N} \mathrm{KOH}$ 로 상층액이 투명하게 변할 때까지 반복한 후 탈수 여과 및 농축하였으며, IS(squalene $0.5164 \mathrm{~g} / 500 \mathrm{~mL}, 1,000$ $\mathrm{ppm})$ hexane에 녹여 $2 \mathrm{~mL}$ 로 mass up한 후 $\mathrm{HP}-1[30$ $\mathrm{m} \times 0.22 \sim 0.32 \mathrm{~mm}$ (i.d.)] column이 장착된 gas chromatograph (Agilent 7890A, Agilent Technologies, CA, USA)를 이용하 여 분석하였다. 이 때 oven 온도는 $260^{\circ} \mathrm{C}$ 까지 $5^{\circ} \mathrm{C} / \mathrm{mim}$ 의 속도로 승온시켜 충분히 warming up하였고 최종 온도인 $280^{\circ} \mathrm{C}$ 에서 10 분간 유지하였으며, injector와 detector(FID) 온도는 각각 $270^{\circ} \mathrm{C}$ 와 $290^{\circ} \mathrm{C}$ 이었다.

\section{열 량}

열량 분석을 위하여 분쇄한 시료 $50 \mathrm{~g}$ 을 취한 후 전처리하 여 calorie meter(6400, Parr Instrument Co., Illinois, Moline, USA)로 분석하였다.

아미노산

시료 $1 \mathrm{~g}$ 에 ethanol $20 \mathrm{~mL}$ 를 가한 후 homogenizer로 10 분 간 교반한 것을 $3,000 \mathrm{rpm}$ 에서 20 분간 원심분리하여 그 상층액을 감압농축하였다. 농축액을 sample dilution buffer $25 \mathrm{~mL}$ 로 용해시키고 sulfosalicylic acid $20 \mathrm{mg}$ 을 가하여 $44^{\circ} \mathrm{C}$ 에서 1 시간 동안 방치시킨 다음, 다시 $3,000 \mathrm{rpm}$ 에서 20 분간 원심분리한 것을 membrane filter $(0.2 \mu \mathrm{m})$ 로 여과시 켜 아미노산 자동분석기(L-8900, Hitachi, Tokyo, Japan)로 $440 \mathrm{~nm}$ 와 $570 \mathrm{~nm}$ 에서 측정하여 정량분석하였다. 칼럼은 cation separation column(내경 $4.6 \times 60 \mathrm{~mm}$, packed with Hitachi custom ion exchange resin)을 사용하였으며, 이 때, 칼럼의 온도는 $20 ~ 85^{\circ} \mathrm{C}$, buffer의 유속은 $0.45 \mathrm{~mL} / \mathrm{min}$, reagent의 유속은 $0.25 \mathrm{~mL} / \mathrm{min}$ 이었으며, $\mathrm{pH}$ 는 $2.90 ~ 7.95$ 의 범위였다.

\section{지방산}

지방산 조성은 시료 $50 \mathrm{~g}$ 과 chloroform : methanol(2 : 1) 용액 $250 \mathrm{~mL}$ 을 homogenizer $3,000 \mathrm{rpm}$ 으로 균질화하여 지질을 추출한 다음 무수황산나트륨을 이용하여 수분을 제거하고 여과액을 $50 \sim 55^{\circ} \mathrm{C}$ 에서 농축하였다. Tricosanic acid $1 \mathrm{~mL}$ 첨가 후 $0.5 \mathrm{~N} \mathrm{NaOH} 1 \mathrm{~mL}$ 를 첨가하였으며, $100^{\circ} \mathrm{C}$ 에서 20 분간 가열하고 30 분간 방냉한 후 삼불화붕소 (BF3) $2 \mathrm{~mL}$ 을 첨가하고 다시 20 분간 가열한 후 30 분간 방냉하였다. Heptane과 $\mathrm{NaCl} 4 \mathrm{~mL}$ 를 첨가한 후 상등액을 취하여 HP-1[30 m×0.22 0.32 mm(i.d.)] column이 장착된 gas chromatograph(Agilent 6890, Agilent Technologies, CA, USA)를 이용하여 분석하였다.

\section{무기성분}

무기성분 함량은 $\mathrm{AOAC}$ 방법에 준하여 측정하였다(8). 
시료 $5 \mathrm{~g}$ 을 크루시블에 취하고 전기회화로(MAS-7000, CEM Corp., Matthews, NC, USA) $600^{\circ} \mathrm{C}$ 에서 12 시간 이상 회화 후 방냉하였으며, 염산용액 $\left(\mathrm{HCl}: \mathrm{H}_{2} \mathrm{O}=1: 1\right) 10$ $\mathrm{mL}$ 를 가하여 하룻밤 방치하여 용해시킨 다음 여과지 (Whatman No.6)로 여과한 것을 시험 용액으로 하였다. 원자 흡광광도계(ICP spectrophotometer, Spectroflame, Spectro Company, Kleve, Germany)를 이용하여 $\mathrm{Ca}, \mathrm{Fe}, \mathrm{K}, \mathrm{Mg}, \mathrm{Na}$, $\mathrm{P}, \mathrm{Zn}$ 의 함량을 분석하였으며, 검량선의 $\mathrm{y}$ 절편 표준편차와 기울기를 이용하여 아래 식에 의하여 검출한계와 정량한계 를 구하였다.

$$
\begin{aligned}
& \text { 검출한 계 }(D L)=\frac{3.3 \times \sigma}{S} \\
& \text { 정 량한 계 }(Q L)=\frac{10 \times \sigma}{S}
\end{aligned}
$$

$$
\begin{aligned}
& \mathrm{S}: \text { 기울기 } \\
& \sigma: \mathrm{y} \text { 절편의 표준편차 }
\end{aligned}
$$

\section{통계처리}

실험결과는 SAS procedure를 이용하여 $\mathrm{p}<0.05$ 수준에서 분산분석과 Duncan's multiple range test(9)를 통해 통계적 유의성을 검정하였다.

\section{결과 및 고찰}

\section{일반성분}

백색육(오리고기, 닭고기)과 말고기의 일반성분을 분석 한 결과는 Table 1에 나타낸 것과 같다. 수분은 오리고기 $74.07 \sim 77.35 \%$, 닭고기 73.13 74.47\%, 말고기 69.17 72.66\%
의 범위였으며, 말고기에서 수분의 함량이 낮을수록 조지 방의 함량이 높은 것을 확인할 수 있었다. 조지방의 함량은 닭고기(가슴살), 오리고기(가슴살)에서 유의적으로 낮은 것으로 나타났으며, 말고기(앞다리<목심<등심), 닭고기(다 리살), 오리고기(다리살)의 순이었다. 조단백질의 함량은 닭고기(가슴살)가 유의적으로 높은 것으로 나타났으며, 말 고기(앞다리살<목심<등심), 오리고기(가슴살<다리살), 닭 고기(다리살)의 순이었다. 조회분의 함량은 오리고기 및 닭고기의 다리살을 제외하고는 유의적 차이가 없는 것으로 나타났다. 농촌진흥청에서 발간한 식품성분표(2011, 제8개 정판)의 오리고기, 닭고기 분석 결과는 본 연구결과에 비하 여 다소 높았으나, 대체로 유사한 경향이었다(10).

\section{콜레스테롤, 열량}

백색육(오리고기, 닭고기)과 말고기의 콜레스테롤 및 열 량을 분석한 결과는 Table 2 에 나타낸 것과 같다. 오리고기, 닭고기, 말고기의 콜레스테롤 함량은 각각 47.48 67.76 $\mathrm{mg} / 100 \mathrm{~g}, 39.27 \sim 53.06 \mathrm{mg} / 100 \mathrm{~g}, 42.09 \sim 45.00 \mathrm{mg} / 100 \mathrm{~g}$ 의 범위로, 일반적으로 고기 내 콜레스테롤 함량은 약 30 120 $\mathrm{mg} / 100 \mathrm{~g}$ 이라는 보고와 일치하였다(11). 토끼고기, 쇠고기, 돼지고기의 콜레스테롤 함량 분석 결과, 각각 $65.3 \mathrm{mg} / 100$ $\mathrm{g}, 64.4 \mathrm{mg} / 100 \mathrm{~g}, 77.5 \mathrm{mg} / 100 \mathrm{~g}$ 이라고 보고된 것과 비교해 볼 때, 백색육(오리고기, 닭고기) 및 말고기의 콜레스테롤 함량은 현저히 낮은 수준임을 알 수 있었다(12). 본 연구에 서 말고기의 콜레스테롤 함량은 망아지 등심의 콜레스테롤 함량을 분석한 연구의 $40 \mathrm{mg} / 100 \mathrm{~g}$ 과는 비슷한 수준이었으 나, 성마 뒷다리 근육의 콜레스테롤 함량을 분석한 연구의 $55 \mathrm{mg} / 100 \mathrm{~g}$ 보다는 낮은 수준으로 나타났다(13,14). 식품의 약품안전처가 정한 콜레스테롤의 하루 섭취 제한량은 300

Table 1. General components of chicken meat, duck meat, and horse meat

\begin{tabular}{lccccccc}
\hline \multirow{2}{*}{$(\%)$} & \multicolumn{2}{c}{ Duck } & \multicolumn{2}{c}{ Chicken } & \multicolumn{2}{c}{ Horse } \\
\cline { 2 - 8 } & Breast & Leg & Breast & Leg & Loin & Chuck roll & Arm picnic \\
\hline Moisture & $77.35 \pm 1.84^{\mathrm{all})}$ & $74.07 \pm 0.56^{\mathrm{b}}$ & $74.47 \pm 0.15^{\mathrm{b}}$ & $73.13 \pm 0.70^{\mathrm{bc}}$ & $69.17 \pm 0.90^{\mathrm{d}}$ & $71.73 \pm 1.51^{\mathrm{c}}$ & $72.66 \pm 0.05^{\mathrm{bc}}$ \\
Crude fat & $0.89 \pm 0.12^{\mathrm{d}}$ & $7.70 \pm 2.83^{\mathrm{a}}$ & $0.74 \pm 0.08^{\mathrm{d}}$ & $7.18 \pm 1.35^{\mathrm{a}}$ & $6.78 \pm 1.66^{\mathrm{ab}}$ & $4.15 \pm 2.00^{\mathrm{bc}}$ & $2.83 \pm 0.27^{\mathrm{cd}}$ \\
Crude protein & $19.81 \pm 1.62^{\mathrm{c}}$ & $18.55 \pm 0.31^{\mathrm{cd}}$ & $23.02 \pm 0.24^{\mathrm{a}}$ & $18.02 \pm 0.39^{\mathrm{d}}$ & $21.45 \pm 0.81^{\mathrm{b}}$ & $21.92 \pm 0.57^{\mathrm{ab}}$ & $21.88 \pm 0.10^{\mathrm{ab}}$ \\
Crude ash & $0.90 \pm 0.07^{\mathrm{a}}$ & $0.74 \pm 0.05^{\mathrm{b}}$ & $0.92 \pm 0.02^{\mathrm{a}}$ & $0.72 \pm 0.02^{\mathrm{b}}$ & $0.86 \pm 0.02^{\mathrm{a}}$ & $0.87 \pm 0.02^{\mathrm{a}}$ & $0.90 \pm 0.02^{\mathrm{a}}$ \\
\hline
\end{tabular}

${ }^{1)}$ Different letters are significantly different at $5 \%$ level.

Table 2. Cholesterol levels and calories in chicken meat, duck meat, and horse meat

\begin{tabular}{lccccccc} 
& \multicolumn{2}{c}{ Duck } & \multicolumn{2}{c}{ Chicken } & \multicolumn{2}{c}{ Horse } \\
\cline { 2 - 8 } & Breast & Leg & Breast & Leg & Loin & Chuck roll & Arm picnic \\
\hline $\begin{array}{l}\text { Cholesterol } \\
(\mathrm{mg} / 100 \mathrm{~g})\end{array}$ & $67.76 \pm 7.19^{\mathrm{al})}$ & $47.48 \pm 3.80^{\mathrm{bc}}$ & $39.27 \pm 2.92^{\mathrm{d}}$ & $53.06 \pm 2.04^{\mathrm{b}}$ & $43.69 \pm 2.00^{\text {cd }}$ & $42.09 \pm 1.98^{\text {cd }}$ & $45.00 \pm 1.61^{\text {cd }}$ \\
Calorie (Kcal/g) & $1.27 \pm 0.11^{\mathrm{e}}$ & $1.72 \pm 0.05^{\mathrm{bc}}$ & $1.48 \pm 0.01^{\mathrm{d}}$ & $1.80 \pm 0.12^{\text {ab }}$ & $1.94 \pm 0.09^{\mathrm{a}}$ & $1.67 \pm 0.16^{\mathrm{bc}}$ & $1.59 \pm 0.02^{\text {cd }}$ \\
\hline
\end{tabular}

${ }^{1)}$ Different letters are significantly different at $5 \%$ level. 
$\mathrm{mg}$ 으로, 백색육(오리고기, 닭고기)과 말고기 중 각각 높은 수치로 나타난 부위를 기준으로 하여 육류만 섭취한다고 가정했을 때 오리고기 $442 \mathrm{~g}$, 닭고기 $565 \mathrm{~g}$, 말고기 666 $\mathrm{g}$ 을 먹을 수 있는 수준이었으며, 말고기의 콜레스테롤 함량 은 백색육(오리고기, 닭고기)에 비해 낮은 수준임을 알 수 있었다[닭고기(가슴살) 제외].

오리고기, 닭고기, 말고기의 열량은 조지방의 함량과 수 준이 유사한 경향이었으며, 오리고기 $1.27 ~ 1.72 \mathrm{kcal} / \mathrm{g}$, 닭고 기 $1.48 \sim 1.80 \mathrm{kcal} / \mathrm{g}$, 말고기 $1.59 \sim 1.94 \mathrm{kcal} / \mathrm{g}$ 으로 나타나 말고기의 열량 분석 결과 $1.43 \sim 2.10 \mathrm{kcal} / \mathrm{g}$ 라고 보고된 것과 유사하였다(15). 오리고기, 닭고기 분석 결과는 농촌진흥청 에서 발간한 식품성분표의 일반성분과는 반대로 본 연구결 과에 비하여 다소 낮은 경향이었으나, 대체로 유사하였다 (10). 말고기(등심, 목심)의 열량은 각각 닭고기(다리살), 오리고기(다리살)와 같은 수준인 것으로 나타났으며, 말고 기(앞다리살)의 열량은 백색육(오리고기, 닭고기)의 가슴 살과 유사하거나 조금 높은 수준인 것으로 나타났다.

\section{아미노산}

백색육(오리고기, 닭고기)과 말고기의 아미노산을 분석 한 결과는 Table 3에 나타낸 것과 같다. Serine, glycine, alanine 등은 좋은 맛을 나타내는 아미노산이라고 알려져
있고, arginine, valine, methionine, isoleucine, phenylalanine 등은 좋지 않은 맛을 나타내는 아미노산이라고 알려져 있다 (16). 본 연구에서 말고기의 serine, glycine, alanine, phenylalanine 함량은 백색육과 유사한 수준인 것으로 나타 났으나, arginine, valine, methionine, isoleucine의 함량은 백 색육보다 낮은 수준으로 나타나 좋지 않은 맛을 가진 아미 노산이 백색육보다 적게 함유되어 있는 것을 알 수 있었다.

백색육(오리고기, 닭고기)과 말고기 모두 감칠맛을 내는 아미노산으로 잘 알려진 glutamic acid의 함량이 5.64 6.95 $\mathrm{g} / 100 \mathrm{~g}$ 으로 가장 많았고, leucine이 4.60 5.46 g/100 g으로 뒤를 이었으며, 그 다음 순으로 말고기는 lysine, aspartic acid, 닭고기, 오리고기는 aspartic acid, lysine으로 분석되었 다. Leucine과 lysine은 필수아미노산으로, 특히 lysine은 곡 류 등 식물성 단백질에 그 함량이 적어 제한아미노산으로 작용하기 쉬운 것으로 알려져 있다. 한편, 닭고기, 오리고기 및 말고기의 아미노산을 각각 분석한 다른 연구에서도 가장 많은 아미노산은 glutamic acid인 것으로 나타나 본 연구결 과와 일치하였다 $(15,17,18)$.

말고기는 다른 육류에 비해 단백질의 영양적 가치가 높 고, 말고기 $100 \mathrm{~g}$ 은 성인 1 일 단백질 요구량의 약 $40 \%$ 를 공급한다고 보고된 바 있다(19). 본 연구에서도 총 아미노산 에 대한 필수 아미노산(어린이)의 비율은 말고기의 등심

Table 3. Amino acid contents of chicken meat, duck meat, and horse meat

\begin{tabular}{|c|c|c|c|c|c|c|c|}
\hline \multirow{2}{*}{$(\mathrm{g} / 100 \mathrm{~g})$} & \multicolumn{2}{|c|}{ Duck } & \multicolumn{2}{|c|}{ Chicken } & \multicolumn{3}{|c|}{ Horse } \\
\hline & Breast & Leg & Breast & Leg & Loin & Chuck roll & Arm picnic \\
\hline Aspartic acid & $4.44 \pm 0.45^{\mathrm{al})}$ & $4.22 \pm 0.45^{\mathrm{abc}}$ & $4.62 \pm 0.38^{\mathrm{a}}$ & $4.25 \pm 0.07^{\mathrm{ab}}$ & $3.69 \pm 0.10^{c}$ & $3.68 \pm 0.12^{\mathrm{c}}$ & $3.82 \pm 0.09^{b c}$ \\
\hline Threonine $^{*}$ & $2.23 \pm 0.27^{\mathrm{a}}$ & $2.14 \pm 0.26^{\mathrm{ab}}$ & $2.17 \pm 0.23^{a b}$ & $2.08 \pm 0.01^{\mathrm{ab}}$ & $1.84 \pm 0.05^{\mathrm{bc}}$ & $1.74 \pm 0.09^{c}$ & $1.89 \pm 0.08^{b c}$ \\
\hline Serine & $1.46 \pm 0.28^{\mathrm{a}}$ & $1.38 \pm 0.26^{\mathrm{a}}$ & $1.28 \pm 0.14^{\mathrm{ab}}$ & $1.33 \pm 0.11^{\mathrm{ab}}$ & $1.16 \pm 0.02^{a b}$ & $1.03 \pm 0.08^{b}$ & $1.15 \pm 0.08^{\mathrm{ab}}$ \\
\hline Glutamic acid & $6.93 \pm 0.64^{\mathrm{a}}$ & $6.71 \pm 0.77^{\mathrm{ab}}$ & $6.95 \pm 0.53^{\mathrm{a}}$ & $6.80 \pm 0.07^{\mathrm{a}}$ & $5.64 \pm 0.15^{\mathrm{c}}$ & $5.64 \pm 0.36^{\mathrm{c}}$ & $5.94 \pm 0.16^{\mathrm{bc}}$ \\
\hline Glycine & $2.36 \pm 0.20^{\mathrm{a}}$ & $1.95 \pm 0.18^{\mathrm{b}}$ & $2.27 \pm 0.26^{\mathrm{ab}}$ & $2.15 \pm 0.08^{\mathrm{a}}$ & $1.94 \pm 0.14^{\mathrm{b}}$ & $2.24 \pm 0.20^{\mathrm{ab}}$ & $2.10 \pm 0.13^{\mathrm{ab}}$ \\
\hline Alanine & $3.52 \pm 0.32^{\mathrm{a}}$ & $3.24 \pm 0.30^{\mathrm{ab}}$ & $3.53 \pm 0.36^{\mathrm{a}}$ & $3.20 \pm 0.08^{\mathrm{ab}}$ & $2.87 \pm 0.09^{b}$ & $3.10 \pm 0.12^{\mathrm{ab}}$ & $3.02 \pm 0.06^{\mathrm{b}}$ \\
\hline Cystine & $1.53 \pm 0.10^{\mathrm{ab}}$ & $1.51 \pm 0.10^{\mathrm{ab}}$ & $1.64 \pm 0.23^{\mathrm{a}}$ & $1.54 \pm 0.19^{\mathrm{ab}}$ & $1.18 \pm 0.07^{c}$ & $1.34 \pm 0.07^{\mathrm{bc}}$ & $1.33 \pm 0.02^{\mathrm{bc}}$ \\
\hline Valine $^{*}$ & $2.48 \pm 0.17^{\mathrm{ab}}$ & $2.30 \pm 0.20^{\mathrm{bc}}$ & $2.61 \pm 0.29^{\mathrm{a}}$ & $2.34 \pm 0.05^{\mathrm{abc}}$ & $2.05 \pm 0.08^{c}$ & $2.04 \pm 0.10^{c}$ & $2.17 \pm 0.07^{\mathrm{c}}$ \\
\hline Methionine $^{*}$ & $1.10 \pm 0.11^{\mathrm{abc}}$ & $1.14 \pm 0.14^{\mathrm{ab}}$ & $1.32 \pm 0.10^{\mathrm{a}}$ & $1.06 \pm 0.27^{\mathrm{abc}}$ & $0.86 \pm 0.08^{c}$ & $0.90 \pm 0.06^{\mathrm{bc}}$ & $1.01 \pm 0.01^{\mathrm{bc}}$ \\
\hline Isoleucine $^{*}$ & $2.56 \pm 0.20^{\mathrm{ab}}$ & $2.45 \pm 0.21^{\mathrm{abc}}$ & $2.73 \pm 0.28^{\mathrm{a}}$ & $2.49 \pm 0.08^{\mathrm{abc}}$ & $2.17 \pm 0.10^{\mathrm{cd}}$ & $2.12 \pm 0.15^{\mathrm{d}}$ & $2.29 \pm 0.09^{\text {bcd }}$ \\
\hline Leucine $^{*}$ & $5.38 \pm 0.54^{\mathrm{a}}$ & $5.07 \pm 0.50^{\mathrm{ab}}$ & $5.46 \pm 0.49^{\mathrm{a}}$ & $5.02 \pm 0.10^{\mathrm{ab}}$ & $4.64 \pm 0.12^{b}$ & $4.60 \pm 0.15^{\mathrm{b}}$ & $4.80 \pm 0.14^{\mathrm{ab}}$ \\
\hline Tyrosine & $2.16 \pm 0.19^{\mathrm{a}}$ & $2.18 \pm 0.20^{\mathrm{a}}$ & $1.62 \pm 0.27^{\mathrm{c}}$ & $2.20 \pm 0.18^{\mathrm{a}}$ & $1.75 \pm 0.18^{b c}$ & $1.86 \pm 0.17^{\mathrm{abc}}$ & $2.03 \pm 0.09^{\mathrm{ab}}$ \\
\hline Phenylalanine ${ }^{*}$ & $2.22 \pm 0.20^{\mathrm{a}}$ & $2.06 \pm 0.18^{\mathrm{a}}$ & $2.20 \pm 0.19^{\mathrm{a}}$ & $2.08 \pm 0.11^{\mathrm{a}}$ & $2.06 \pm 0.03^{\mathrm{a}}$ & $2.08 \pm 0.03^{\mathrm{a}}$ & $2.13 \pm 0.05^{\mathrm{a}}$ \\
\hline Lysine $^{*}$ & $4.10 \pm 0.39^{\mathrm{a}}$ & $3.90 \pm 0.34^{\mathrm{a}}$ & $4.24 \pm 0.40^{\mathrm{a}}$ & $4.06 \pm 0.09^{\mathrm{a}}$ & $3.86 \pm 0.07^{\mathrm{a}}$ & $3.87 \pm 0.19^{\mathrm{a}}$ & $4.01 \pm 0.10^{\mathrm{a}}$ \\
\hline Histidine $^{* *}$ & $1.40 \pm 0.13^{\mathrm{d}}$ & $1.46 \pm 0.13^{\mathrm{cd}}$ & $1.97 \pm 0.17^{\mathrm{a}}$ & $1.50 \pm 0.11^{\mathrm{cd}}$ & $1.78 \pm 0.07^{\mathrm{ab}}$ & $1.66 \pm 0.06^{\mathrm{bc}}$ & $1.77 \pm 0.13^{\mathrm{ab}}$ \\
\hline Arginine $^{* *}$ & $3.69 \pm 0.33^{\mathrm{a}}$ & $3.45 \pm 0.37^{7 \mathrm{~b}}$ & $3.64 \pm 0.44^{\mathrm{a}}$ & $3.46 \pm 0.18^{\mathrm{ab}}$ & $2.88 \pm 0.07^{c}$ & $2.99 \pm 0.07^{\mathrm{bc}}$ & $3.07 \pm 0.08^{\mathrm{bc}}$ \\
\hline Proline & $2.67 \pm 0.21^{\mathrm{a}}$ & $2.41 \pm 0.25^{\mathrm{ab}}$ & $2.54 \pm 0.24^{\mathrm{a}}$ & $2.49 \pm 0.16^{\mathrm{ab}}$ & $2.18 \pm 0.13^{b}$ & $2.44 \pm 0.07^{\mathrm{ab}}$ & $2.35 \pm 0.11^{\mathrm{ab}}$ \\
\hline $\begin{array}{l}\text { Ratio of EAA } \\
\text { for adult }(\%)\end{array}$ & $39.96 \pm 0.43^{\mathrm{bc}}$ & $40.09 \pm 0.57^{\mathrm{bc}}$ & $40.82 \pm 0.23^{\mathrm{ab}}$ & $39.82 \pm 0.10^{\mathrm{c}}$ & $41.10 \pm 0.60^{\mathrm{a}}$ & $40.02 \pm 0.51^{\mathrm{bc}}$ & $40.73 \pm 0.53^{\mathrm{ab}}$ \\
\hline $\begin{array}{l}\text { Ratio of EAA } \\
\text { for children }{ }^{* *}(\%)\end{array}$ & $50.10 \pm 0.43^{\mathrm{c}}$ & $50.41 \pm 0.68^{\mathfrak{c}}$ & $51.87 \pm 0.29^{\mathrm{a}}$ & $50.14 \pm 0.12^{\mathrm{c}}$ & $52.04 \pm 0.78^{\mathrm{a}}$ & $50.77 \pm 0.49^{\mathrm{bc}}$ & $51.53 \pm 0.73^{\mathrm{ab}}$ \\
\hline
\end{tabular}

${ }^{1}$ Different letters are significantly different at $5 \%$ level.

* Essential amino acids (EAA) for adult; ${ }^{* *}$ Essential amino acids (EAA) for children. 
부위와 닭고기(가슴살)에서 각각 $52.04 \mathrm{~g} / 100 \mathrm{~g}, 51.87 \mathrm{~g} / 100$ $\mathrm{g}$ 으로 유의적으로 높은 것으로 나타났으며, 말고기의 다른 부위(목심, 앞다리)도 닭고기, 오리고기와 유사하거나 더 높은 것으로 나타나 말고기는 양질의 단백질 공급원으로 손색이 없을 것으로 생각된다.

\section{지방산}

백색육(오리고기, 닭고기)과 말고기의 지방산을 분석한 결과는 Table 4에 나타낸 것과 같다. 지방산 중 가장 높은 비율을 차지한 것은 품종 및 부위와 관계 없이 oleic acid였 으며, palmitic acid, linoleic acid가 그 뒤를 잇는 것으로 나타났다. Linoleic acid는 필수지방산 중 하나이며, oleic acid와 palmitic acid는 혈중콜레스테롤 감소는 물론 피부건 강에 좋아 기능성 물질로 각광받고 있는 palmitoleic acid 합성에 이용되는 지방산이다.

Palmitoleic acid의 비율은 말고기 8.63 9.30\%, 오리고기
$3.26 \sim 3,63 \%$, 닭고기 7.10 7.62\%로 말고기가 백색육(오리 고기, 닭고기)에 비해 최대 2.6배 가량 높은 것으로 확인되 었으며, 특히 말고기 등심 부위에서 유의적으로 높은 것으 로 나타났다. 또한, 필수지방산 중 하나인 linolenic acid의 함량이 말고기에서 유의적으로 높은 것으로 나타났고, 부 위별 유의성은 없었다. 닭고기와 오리고기 간의 유의적 차 이는 없는 것으로 나타났으며, 말고기가 백색육(오리고기, 닭고기)에 비해 최대 4.1배 가량 높은 것으로 확인되었다. 이는 말은 대부분 초원에서 방목되어 목초 사육되기 때문인 것으로 생각되며, grass silage를 급여한 쇠고기에서 linolenic acid를 포함한 n-3 계열 지방산의 합성이 증가되었 다는 연구결과가 뒷받침해준다(20).

오리고기와 닭고기의 지방산 비교 결과 본 연구와 유사 한 경향으로 나타났으며(21), $\mathrm{C}_{18: 0} / \mathrm{C}_{18: 2}$ 의 비율이 클수록 지방의 경도가 크고 두께 또한 두껍다는 것을 나타낸다고 보고된 바 있다(22). 말고기는 0.23 0.25의 범위였으나, 닭

Table 4. Fatty acid contents of chicken meat, duck meat, and horse meat

\begin{tabular}{|c|c|c|c|c|c|c|c|}
\hline \multirow{2}{*}{$(\%)$} & \multicolumn{2}{|c|}{ Duck } & \multicolumn{2}{|c|}{ Chicken } & \multicolumn{3}{|c|}{ Horse } \\
\hline & Breast & Leg & Breast & Leg & Loin & Chuck roll & Arm picnic \\
\hline $\begin{array}{l}\text { Myristic acid } \\
\quad\left(\mathrm{C}_{14: 0}\right)\end{array}$ & $0.72 \pm 0.03^{\mathrm{d} 1)}$ & $0.74 \pm 0.02^{\mathrm{d}}$ & $1.08 \pm 0.04^{\mathrm{c}}$ & $1.1 \pm 0.04^{\mathrm{c}}$ & $4.43 \pm 0.18^{\mathrm{a}}$ & $4.08 \pm 0.24^{b}$ & $4.19 \pm 0.22^{\mathrm{ab}}$ \\
\hline $\begin{array}{l}\text { Palmitic acid } \\
\qquad\left(\mathrm{C}_{16: 0}\right)\end{array}$ & $22.07 \pm 0.37^{\mathrm{d}}$ & $23.72 \pm 0.30^{c}$ & $23.83 \pm 0.81^{\mathrm{c}}$ & $23.64 \pm 0.71^{\mathrm{c}}$ & $28.71 \pm 0.27^{\mathrm{a}}$ & $26.98 \pm 0.36^{b}$ & $27.62 \pm 0.39^{b}$ \\
\hline $\begin{array}{l}\text { Palmitoleic acid } \\
\quad\left(\mathrm{C}_{16: 1}, \mathrm{n}-\mathrm{-}\right)\end{array}$ & $3.63 \pm 0.31^{\mathrm{d}}$ & $3.26 \pm 0.52^{\mathrm{d}}$ & $7.62 \pm 0.26^{\mathrm{bc}}$ & $7.1 \pm 1.17^{\mathrm{c}}$ & $9.3 \pm 0.72^{a}$ & $8.66 \pm 0.45^{\mathrm{ab}}$ & $8.63 \pm 0.11^{\mathrm{ab}}$ \\
\hline $\begin{array}{l}\text { Stearic acid } \\
\quad\left(\mathrm{C}_{18: 0}\right)\end{array}$ & $7.62 \pm 0.73^{\mathrm{a}}$ & $7.87 \pm 0.90^{\mathrm{a}}$ & $6.31 \pm 0.07^{b}$ & $6.29 \pm 0.62^{b}$ & $3.83 \pm 0.22^{\mathrm{c}}$ & $4.52 \pm 0.45^{\mathrm{c}}$ & $4.13 \pm 0.17^{\mathrm{c}}$ \\
\hline $\begin{array}{l}\text { Oleic acid } \\
\left(\mathrm{C}_{18: 1}, \mathrm{n}-9\right)\end{array}$ & $49.2 \pm 1.25^{\mathrm{a}}$ & $48.02 \pm 1.30^{\mathrm{a}}$ & $44.75 \pm 1.02^{b}$ & $45.63 \pm 1.42^{b}$ & $34.08 \pm 0.66^{\mathrm{C}}$ & $33.64 \pm 1.27^{\mathrm{c}}$ & $34.16 \pm 0.38^{c}$ \\
\hline $\begin{array}{l}\text { Linoleic acid } \\
\left(\mathrm{C}_{18: 2,2} \mathrm{n}-6\right)^{\star}\end{array}$ & $13.69 \pm 0.20^{c}$ & $13.37 \pm 0.46^{\mathrm{C}}$ & $14.46 \pm 1.09^{\mathrm{bc}}$ & $14.52 \pm 2.12^{\mathrm{bc}}$ & $16.32 \pm 0.91^{\mathrm{ab}}$ & $18.23 \pm 0.63^{\mathrm{a}}$ & $17.66 \pm 0.73^{\mathrm{a}}$ \\
\hline $\begin{array}{l}\text { X-Linolenic acid } \\
\left(\mathrm{C}_{18: 3}, \mathrm{n}-6\right)\end{array}$ & $0.12 \pm 0.04^{\mathrm{bc}}$ & $0.11 \pm 0.02^{c}$ & $0.16 \pm 0.02^{\mathrm{ab}}$ & $0.18 \pm 0.04^{\mathrm{a}}$ & $0.04 \pm 0.01^{\mathrm{d}}$ & $0.06 \pm 0.02^{\mathrm{d}}$ & $0.04 \pm 0.00^{\mathrm{d}}$ \\
\hline $\begin{array}{l}\text { Linolenic acid } \\
\left(\mathrm{C}_{18: 3}, \mathrm{n}-3\right)^{\star}\end{array}$ & $0.58 \pm 0.02^{b}$ & $0.6 \pm 0.02^{\mathrm{b}}$ & $0.60 \pm 0.03^{\mathrm{b}}$ & $0.61 \pm 0.07^{b}$ & $2.4 \pm 0.23^{\mathrm{a}}$ & $2.45 \pm 0.10^{\mathrm{a}}$ & $2.53 \pm 0.45^{\mathrm{a}}$ \\
\hline $\begin{array}{l}\text { Gondoic acid } \\
\left(\mathrm{C}_{20: 1}, \mathrm{n}-9\right)\end{array}$ & $0.72 \pm 0.05^{\mathrm{a}}$ & $0.59 \pm 0.14^{b}$ & $0.56 \pm 0.04^{b}$ & $0.56 \pm 0.04^{b}$ & $0.52 \pm 0.03^{\mathrm{b}}$ & $0.48 \pm 0.05^{\mathrm{b}}$ & $0.5 \pm 0.02^{b}$ \\
\hline $\begin{array}{l}\text { Arachidonic acid } \\
\left(\mathrm{C}_{20: 4,4} \mathrm{n}-6\right)^{6}\end{array}$ & $1.65 \pm 0.42^{\mathrm{a}}$ & $1.74 \pm 0.47^{\mathrm{a}}$ & $0.63 \pm 0.23^{b}$ & $0.37 \pm 0.08^{b}$ & $0.36 \pm 0.04^{b}$ & $0.91 \pm 0.47^{b}$ & $0.53 \pm 0.06^{b}$ \\
\hline $\begin{array}{c}\text { Saturated } \\
\text { fatty acid (SFA) }\end{array}$ & $30.41 \pm 0.94^{\mathrm{c}}$ & $32.33 \pm 0.98^{b}$ & $31.22 \pm 0.84^{\mathrm{bc}}$ & $31.04 \pm 0.92^{\mathrm{bc}}$ & $36.98 \pm 0.30^{\mathrm{a}}$ & $35.58 \pm 0.34^{\mathrm{a}}$ & $35.94 \pm 0.73^{\mathrm{a}}$ \\
\hline $\begin{array}{c}\text { Unsaturated } \\
\text { fatty acid (UFA) }\end{array}$ & $69.59 \pm 0.94^{\mathrm{a}}$ & $67.67 \pm 0.98^{b}$ & $68.78 \pm 0.84^{\mathrm{ab}}$ & $68.96 \pm 0.92^{\mathrm{ab}}$ & $63.02 \pm 0.30^{\mathrm{c}}$ & $64.42 \pm 0.34^{\mathrm{c}}$ & $64.06 \pm 0.73^{\mathrm{c}}$ \\
\hline $\begin{array}{c}\text { Polynsaturated } \\
\text { fatty acid (PUFA) }\end{array}$ & $16.04 \pm 0.67^{\mathrm{c}}$ & $15.81 \pm 0.93^{\mathrm{c}}$ & $15.85 \pm 1.26^{\mathrm{c}}$ & $15.68 \pm 2.30^{c}$ & $19.13 \pm 1.08^{b}$ & $21.64 \pm 1.02^{\mathrm{a}}$ & $20.77 \pm 1.16^{\mathrm{ab}}$ \\
\hline PUFA/SFA & $0.53 \pm 0.01^{\mathrm{bc}}$ & $0.49 \pm 0.01^{\mathrm{c}}$ & $0.51 \pm 0.05^{\mathrm{bc}}$ & $0.51 \pm 0.07^{\mathrm{bc}}$ & $0.52 \pm 0.02^{\mathrm{bc}}$ & $0.61 \pm 0.02^{\mathrm{a}}$ & $0.58 \pm 0.04^{\mathrm{ab}}$ \\
\hline $\mathrm{C}_{18: 0} / \mathrm{C}_{182}$ & $0.56 \pm 0.05^{\mathrm{a}}$ & $0.59 \pm 0.05^{\mathrm{a}}$ & $0.44 \pm 0.03^{b}$ & $0.44 \pm 0.04^{b}$ & $0.24 \pm 0.02^{c}$ & $0.25 \pm 0.02^{c}$ & $0.23 \pm 0.02^{\mathrm{c}}$ \\
\hline Ratio of $\mathrm{EFA}^{*}$ & $15.92 \pm 0.63^{\mathrm{c}}$ & $15.71 \pm 0.91^{c}$ & $15.69 \pm 1.25^{\mathrm{c}}$ & $15.50 \pm 2.26^{c}$ & $19.08 \pm 1.08^{b}$ & $21.59 \pm 1.00^{\mathrm{a}}$ & $20.72 \pm 1.16^{\mathrm{ab}}$ \\
\hline
\end{tabular}

${ }^{1)}$ Different letters are significantly different at $5 \%$ level.

"Essential fatty acids (EFA). 
고기는 0.44 , 오리고기는 0.56 0.59의 범위로 유의적 차이 가 있는 것으로 나타나 이들의 육 내 지방조직이 말고기보 다 더 두껍고 단단함을 예측할 수 있었다.

불포화지방산의 비율은 오리고기 $67.67 \sim 69.59 \%$, 닭고기 68.78 68.96\%로 말고기의 63.02 64.06\%보다 높은 것으로 나타났으나, 어류에 많다고 알려진 다가불포화지방산 (PUFA)의 비율은 말고기가 19.13 21.64\%로 오리고기 $15.81 \sim 16.04 \%$, 닭고기 $15.68 \sim 15.85 \%$ 에 비해 유의적으로 높 은 것으로 나타나 말고기는 다른 육류와 비교하여 포화지방 산이 매우 낮으며 어류처럼 다가불포화지방산(PUFA)이 풍 부한 것으로 나타났다는 연구결과와 일치하였다(23). 또한, 식생활에서 포화지방산은 줄이고 다가불포화지방산 (PUFA)의 섭취를 늘리는 것이 권장된다고 보고된 바 있으 며(24), 말고기는 필수지방산의 비율이 19.08 21.59\%로 오 리고기 15.71 15.91\%, 닭고기 15.50 15.69\%보다 유의적으 로 높은 것으로 나타나 웰빙식육으로 성장할 가능성이 있음 을 확인할 수 있었다.

\section{무기성분}

백색육(오리고기, 닭고기)과 말고기의 무기성분을 분석 한 결과는 Table 5 에 나타낸 것과 같다. 이 때 $\mathrm{Ca}, \mathrm{Fe}, \mathrm{K}$, $\mathrm{Mg}, \mathrm{Na}, \mathrm{P}, \mathrm{Zn}$ 의 검출한계 및 정량한계는 각각 0.0051 $\mathrm{mg} / \mathrm{L}$ 및 $0.0154 \mathrm{mg} / \mathrm{L}, 0.0023 \mathrm{mg} / \mathrm{L}$ 및 $0.0068 \mathrm{mg} / \mathrm{L}$, $0.2693 \mathrm{mg} / \mathrm{L}$ 및 $0.8161 \mathrm{mg} / \mathrm{L}, 0.0038 \mathrm{mg} / \mathrm{L}$ 및 0.0114 $\mathrm{mg} / \mathrm{L}, 0.0228 \mathrm{mg} / \mathrm{L}$ 및 $0.0690 \mathrm{mg} / \mathrm{L}, 0.0711 \mathrm{mg} / \mathrm{L}$ 및 $0.2155 \mathrm{mg} / \mathrm{L}, 0.0008 \mathrm{mg} / \mathrm{L}$ 및 $0.0025 \mathrm{mg} / \mathrm{L}$ 였으며, 분석결 과 대부분의 R2값이 0.999 이상의 양호한 직선성을 나타냈 다 $\left(\mathrm{Ca}\right.$ 의 $\mathrm{R}^{2}$ 값은 ${ }^{0.997)}$.

무기질은 체내에서 합성되지 않기 때문에 식품으로 섭취 해야 하는데, 이들의 무기성분 함량은 $\mathrm{K}, \mathrm{P}, \mathrm{Na}, \mathrm{Mg}, \mathrm{Ca}$, $\mathrm{Zn}, \mathrm{Fe}$ 의 순이었으며, 백색육(다리살)의 경우에만 $\mathrm{K}, \mathrm{P}, \mathrm{Na}$, $\mathrm{Mg}, \mathrm{Ca}, \mathrm{Fe}, \mathrm{Zn}$ 의 순으로 나타났다. $\mathrm{Fe}$ 의 함량은 말고기에서 $34.37 \sim 37.21 \mathrm{mg} / \mathrm{kg}$ 으로 유의적으로 높았고, 오리고기 $18.06 \sim 32.66 \mathrm{mg} / \mathrm{kg}$, 닭고기 $6.05 \sim 11.12 \mathrm{mg} / \mathrm{kg}$ 순이었으며, 말고기의 부위별 유의성은 인정되지 않았으나, 오리고기
및 닭고기에서는 다리살보다 가슴살에서 $\mathrm{Fe}$ 의 함량이 유의 적으로 높은 것으로 나타났다. $\mathrm{Na}$ 의 경우 말고기가 $563.11 \sim 653.22 \mathrm{mg} / \mathrm{kg}$ 으로 오리고기 $1014.30 \sim 1073.81 \mathrm{mg} / \mathrm{kg}$, 닭고기 $711.12 ~ 937.38 \mathrm{mg} / \mathrm{kg}$ 에 비해 낮은 것을 알 수 있었 으며, $\mathrm{Zn}$ 의 경우 말고기가 $46.86 ~ 56.48 \mathrm{mg} / \mathrm{kg}$ 으로 오리고 기 $11.88 \sim 24.71 \mathrm{mg} / \mathrm{kg}$, 닭고기 $5.58 \sim 14.52 \mathrm{mg} / \mathrm{kg}$ 에 비해 유의적으로 높은 것으로 나타났다. 뀡과 청둥오리 및 말고 기의 무기성분을 각각 분석한 연구에서도 $\mathrm{K}, \mathrm{P}, \mathrm{Na}, \mathrm{Mg}$, $\mathrm{Ca}$ 의 순으로 나타나 본 연구결과와 유사하였다 $(25,26)$.

식품의약품안전처 영양소 기준치표 기준에 따르면 $\mathrm{Ca}$, $\mathrm{Fe}, \mathrm{K}, \mathrm{Mg}, \mathrm{Na}, \mathrm{P}, \mathrm{Zn}$ 의 일일 권장량은 각각 $700 \mathrm{mg}, 15$ $\mathrm{mg}, 3,500 \mathrm{mg}, 315 \mathrm{mg}, 2,000 \mathrm{mg}, 700 \mathrm{mg}, 8.5 \mathrm{mg}$ 으로 부위에 상관 없이 평균으로 계산했을 때, 말고기 $100 \mathrm{~g}$ 섭취 시 각각 일일 권장량의 $0.8 \%, 23.7 \%, 9.0 \%, 7.7 \%, 3.0 \%, 31.2 \%$, $59.1 \%$ 를 충족할 수 있는 것으로 나타나 말고기는 무기질의 좋은 공급원이 될 수 있음을 알 수 있었다.

\section{요 약}

본 연구에서는 소비자들의 이해를 돕고자 건강에 좋은 육류로 알려져 있는 백색육(오리고기, 닭고기)와 말고기의 식품학적 성분을 비교하여 기초자료를 얻고자 하였다. 말 고기는 저지 방 고단백 저콜레스테롤 육류임을 확인할 수 있었으며, 총 아미노산에 대한 필수 아미노산(어린이)의 비율은 말고기의 등심 부위와 닭고기(가슴살)이 유의적으 로 높은 것으로 나타났다. 말고기의 palmitoleic acid의 비율 은 오리고기 및 닭고기에 비해 최대 2.6배 가량, linolenic acid의 비율은 최대 4.1배 가량 높은 것으로 나타났으며, 유의적 차이가 인정되었다. 다가불포화지방산(PUFA)의 비 율은 말고기가 19.13 21.64\%로 오리고기 15.81 16.04\%, 닭 고기 15.68 15.85\%에 비해 유의적으로 높은 것으로 나타났 으며, 필수지방산의 비율이 19.08 21.59\%로 오리고기 15.71 15.91\%, 닭고기 $15.50 ~ 15.69 \%$ 보다 유의적으로 높았 다. 무기성분 함량은 $\mathrm{K}, \mathrm{P}, \mathrm{Na}, \mathrm{Mg}, \mathrm{Ca}, \mathrm{Zn}, \mathrm{Fe}$ 의 순이었으며

Table 5. Mineral composition of chicken meat, duck meat, and horse meat

\begin{tabular}{cccccccc}
\hline \multirow{2}{*}{$(\mathrm{mg} / \mathrm{kg})$} & \multicolumn{2}{c}{ Duck } & \multicolumn{2}{c}{ Chicken } & \multicolumn{3}{c}{ Horse } \\
\cline { 2 - 8 } & Breast & Leg & Breast & Leg & Loin & Chuck roll & Arm picnic \\
\hline $\mathrm{Ca}$ & $82.21 \pm 5.85^{\mathrm{bl})}$ & $87.19 \pm 4.08^{\mathrm{ab}}$ & $70.69 \pm 6.91^{\mathrm{c}}$ & $93.51 \pm 4.68^{\mathrm{a}}$ & $50.71 \pm 2.10^{\mathrm{d}}$ & $62.85 \pm 3.73^{\mathrm{c}}$ & $53.54 \pm 3.07^{\mathrm{d}}$ \\
$\mathrm{Fe}$ & $32.66 \pm 4.58^{\mathrm{a}}$ & $18.06 \pm 3.92^{\mathrm{b}}$ & $11.12 \pm 0.93^{\mathrm{c}}$ & $6.05 \pm 0.80^{\mathrm{d}}$ & $37.21 \pm 0.95^{\mathrm{a}}$ & $35.23 \pm 1.40^{\mathrm{a}}$ & $34.37 \pm 0.99^{\mathrm{a}}$ \\
$\mathrm{K}$ & $2272.78 \pm 203.53^{\mathrm{b}}$ & $2157.97 \pm 224.19^{\mathrm{b}}$ & $3024.30 \pm 103.54^{\mathrm{a}}$ & $2186.44 \pm 123.02^{\mathrm{b}}$ & $3099.49 \pm 81.82^{\mathrm{a}}$ & $3093.41 \pm 128.33^{\mathrm{a}}$ & $3285.08 \pm 86.18^{\mathrm{a}}$ \\
$\mathrm{Mg}$ & $214.40 \pm 12.81^{\mathrm{d}}$ & $201.13 \pm 11.04^{\mathrm{d}}$ & $295.26 \pm 10.32^{\mathrm{a}}$ & $213.62 \pm 10.81^{\mathrm{d}}$ & $244.36 \pm 8.63^{\mathrm{bc}}$ & $232.42 \pm 9.93^{\mathrm{c}}$ & $252.62 \pm 4.62^{\mathrm{b}}$ \\
$\mathrm{Na}$ & $1014.30 \pm 122.75^{\mathrm{ab}}$ & $1073.81 \pm 58.24^{\mathrm{a}}$ & $711.12 \pm 27.28^{\mathrm{c}}$ & $937.38 \pm 77.38^{\mathrm{b}}$ & $563.11 \pm 23.42^{\mathrm{d}}$ & $653.22 \pm 33.51^{\text {cd }}$ & $591.62 \pm 43.28^{\mathrm{d}}$ \\
$\mathrm{P}$ & $2057.86 \pm 113.41^{\mathrm{b}}$ & $1880.22 \pm 69.90^{\mathrm{c}}$ & $2287.16 \pm 77.66^{\mathrm{a}}$ & $1803.12 \pm 35.30^{\mathrm{c}}$ & $2171.14 \pm 32.98^{\mathrm{ab}}$ & $2126.52 \pm 70.64^{\mathrm{b}}$ & $2252.14 \pm 13.76^{\mathrm{a}}$ \\
$\mathrm{Zn}$ & $11.88 \pm 0.56^{\text {de }}$ & $24.71 \pm 1.82^{\mathrm{c}}$ & $5.58 \pm 0.73^{\mathrm{e}}$ & $14.52 \pm 1.74^{\mathrm{d}}$ & $46.86 \pm 7.98^{\mathrm{b}}$ & $56.48 \pm 8.24^{\mathrm{a}}$ & $47.42 \pm 3.88^{\mathrm{b}}$ \\
\hline
\end{tabular}

${ }^{10}$ Different letters are significantly different at $5 \%$ level. 
[백색육(다리살) 제외], 말고기의 $\mathrm{Fe}$ 및 $\mathrm{Zn}$ 의 함량이 백색육 (오리고기, 닭고기)에 비해 높은 것으로 나타났다. 이러한 성분 분석결과는 말고기가 닭고기나 오리고기보다 식품영 양적 가치가 더 우수함을 보여주었다.

\section{References}

1. Jeon SW, Choi SC, Kim KH (2013) Consumer attitudes and purchase intentions toward horse meat. Korean $\mathbf{J}$ Agric Management Policy, 40, 566-591

2. Oh WY, Lee JW, Lee CE, Ko MS, Jeong JH (2009) Analysis of consumers preferences and behavior with regard to horse meat using a structured survey questionnaire. Anim Sci J, 80, 716-23

3. Devine R (1996) The market for meat products in 1995. Meat and Meat Products, 17, 79-90

4. Seong PN, Lee CE, Kim JH, Park BY, Hah KH, Ko MS (2006) Effect of replacing pork with horse meat on quality characteristics of emulsion-type sausage. Korean J Anim Sci Technol, 48, 739-746

5. Seong PN, Lee CE, Kim JH, Cho SH, Hah KH, Lim DG, Kim DH, Lee JM, Ko MS (2008) Effect of horse meat content on the quality and sensory characteristics of press ham. Korean J Food Sci Ani Resour, 28, 9-13

6. Gill CO (2005) Safety and storage stability of horse meat for human consumption. Meat Sci, 71, 506-513

7. Gill CO, Landers C (2005) Microbiological condition of horse meat prepared at a North American packing plant, and control of the temperatures of product air freighted to Europe. Meat Sci, 69, 501-507

8. AOAC (1990) Official Methods of analysis. 15th ed, Association of Official Analytical Chemists, Washington DC, USA

9. SAS (1998) SAS User's Guide: Statistics, 3th ed, SAS Institute Statistical Analysis System, Cary, NC, USA

10. Rural Resource Development Institute (2011) Food composition table. 8th ed, Rural Resource Development Institute Rural Development Administration, Suwon, Korea, p 238-275

11. Cho SH, Seong PN, Kim JH, Park BY, Baek BH, Lee YJ, In TS, Lee JM, Kim DH, Ahn CN (2008) Calorie, cholesterol, collagen, free amino acids, nucleotide-related compounds and fatty acid composition of Hanwoo steer beef with $1^{++}$quality grade. Korean J Anim Sci Technol, 28, 333-343

12. Lee YC, Cho HC (1977) Studies on lipids and proteins of rabbit meat. J Nutrition Health, 10, 18-26

13. Catalano A, Quarantelli A (1979) Carcass characteristics and chemical composition of the meat of foals bromatological dairy. Clin Vet, 102, 498-506

14. Sinclair AJ, Slattery WJ, O'Dea K (1982) The analysis of polyunsaturated fatty acids in meat by capillary gas-liquid chromatography. J Sci Food Agric, 33, 771-776

15. Yoo IJ, Park BS, Chung CJ, Kim KI (1993) A study on nutritive value of horse meat. Korean J Anim Sci Technol, 35, 131-137

16. Eichhorn JM, Bailey CM, Blomquist GJ (1985) Fatty acid composition of muscle and adipose tissue from crossbred bulls and steers. J Anim Sci, 61, 892-904

17. Ahn DH, Park SY (2002) Studies on components related to taste such as free amino acids and nucleotides in Korean native chicken meat. Korean Soc Food Sci Nutr, 31, 547-552

18. Kim DP, Nam HK (1977) Studies on the duck-meat. (1) Amino acid composition of duck-meat protein. Korean Soc Food Sci Nutr, 6, 61-65

19. Bodwell CE, Anderson BA (1986) Nutritional composition and value of meat and meat productions, In: Bechtel PJ(Editor). Muscle as Food. Academic Press, Orlando, USA, p 321-369

20. Warren HE, Scollan ND, Enser M, Hughes SI, Richardson RI, Wood JD (2008) Effects of breed and a concentrate or grass silage diet on beef quality in cattle of 3 ages. I. Animal performance, carcass quality and muscle fatty acid composition. Meat Sci, 78, 256-269

21. Nam HK, Lee YO (1981) A study of the bio-nutritional evaluation of duck-meat. J Nutr Health, 14, 16-25

22. Busboom JR, Miller GJ, Field RA, Crouse JD, Riley ML, Nelms GE, Ferrell CL (1981) Characteristics of fat from heavy ram and wether lambs. J Anim Sci, 52, 83-92

23. Ciappellano, Salvatore, Riso, Patrizia, Simonetti, Paolo, Contino, Daniele, Del Bo', Cristian (2009) Effect of horse meat consumption on iron status, lipid profile and fatty acid composition of red blood cell membrane: preliminary study. Societa Italiana di Radiologia Medica, Milan, Italy

24. Okuyama H, Ikemoto A (1999) Needs to modify the fatty acid composition of meats for human health. Proceed. 45th Int. Cong. Meat Science Technology, Yokohama, Japan, p 638-640

25. Kim KJ, Oh HR, Oh MJ (1996) Chemical composition of special poultry (Pheasant, Chungdung wild duck, and Ogol fowl) meats. J Agric Sci (Chungnam National 
University, Korea), 23, 90-98

26. Chae HS, Kim NY, Cho IC, Cho SR, Cho WM, Park YS, Oh SA, Jang AR, Seong PN, Ko MS (2013) Effect of dietary supplementation of dried-citrus pulp and wheat bran on growth and meat quality in horses. J Anim Sci Technol, 55, 219-227 